\title{
PENGARUH AIR MINERAL DAN AIR MINUM BEROKSIGEN TERHADAP SATURASI OKSIGEN DARAH PESENAM ZUMBA
}

\author{
${ }^{1}$ Brenda N. E. Pelealu \\ ${ }^{2}$ Maya E.W. Moningka \\ ${ }^{2}$ Jimmy F. Rumampuk \\ ${ }^{1}$ Kandidat Skripsi Bagian Fisika Kedokteran Universitas Sam Ratulangi Manado \\ ${ }^{2}$ Bagian Fisika Kedokteran Universitas Sam Ratulangi Manado \\ Email: bpelealu11_233@yahoo.com
}

\begin{abstract}
During physical activity, blood flow and oxygen usage will increase in order to transport oxygen which is required by muscles during exercise. One of the parameters to check the amount of oxygen that is bound to hemoglobin is oxygen saturation. This study aimed to determine the level of blood oxygen saturation of those who consumed mineral water and high oxygenated water during zumba gymnastics. This was an analytical experiments method with pre and post test approach. Total samples were 31 people who met the criteria and were willing to become the respondents. Data were analyzed using Wilcoxon Test. The results showed that the oxygen saturation before and after consuming mineral water (97.5 \pm 0.9$)$ and $(97.7 \pm 1.03)$ meanwhile before and after consuming high oxygenated water $(97.6 \pm 0.75)$ and $(98.7 \pm 0.44)$. The Wilcoxon test showed that there was a significant difference of blood oxygen saturation between before and after consuming high-oxygenated water $(p=0.000)$ whereas for other respondents who consumed mineral water, there was no significant difference in their condition before and after consuming mineral water $(p=0.198)$. Conclusion: There was a higher increase in blood oxygen saturation value before and after consuming oxygenated water compared to before and after consuming mineral water.
\end{abstract}

Keywords: oxygen saturation, mineral water, and oxygenated water.

\begin{abstract}
Abstrak: Ketika beraktivitas fisik, aliran darah dan penggunaan oksigen akan meningkat untuk mengangkut oksigen yang diperlukan pada otot selama latihan. Salah satu parameter untuk melihat kadar oksigen yang berikatan dengan hemoglobin adalah Saturasi Oksigen. Penelitian ini bertujuan untuk mengetahui nilai saturasi oksigen darah pada orang yang mengkonsumsi air mineral dan air beroksigen tinggi pada senam zumba. Penelitian ini menggunakan metode analitik eksperimental dengan pendekatan pre and post test. Sampel penelitian berjumlah 31 orang yang memenuhi kriteria dan bersedia menjadi responden. Analisis data dilakukan dengan menggunakan uji Wilcoxon test. Hasil penelitian menunjukkan bahwa saturasi oksigen sebelum dan sesudah mengonsumsi air mineral $(97,5 \pm 0,9)$ dan $(97,7 \pm 1,03)$ sedangkan sebelum dan sesudah mengonsumsi air beroksigen tinggi $(97,6 \pm 0,75)$ dan $(98,7 \pm 0,44)$. Hasil uji Wilcoxon test menunjukkan perbedaan yang signifikan pada responden sebelum dan sesudah mengonsumsi air beroksigen $(p=0,000)$ sedangkan ketika responden mengonsumsi air mineral terdapat perbedaan yang tidak signifikan pada kondisi sebelum dan sesudah mengkonsumsi air mineral $(\mathrm{p}=0,198)$. Simpulan: Terjadi peningkatan yang lebih tinggi dalam nilai saturasi oksigen darah sebelum dan sesudah mengkonsumsi air beroksigen dibandingkan dengan air mineral.
\end{abstract}

Kata kunci: saturasi oksigen, air mineral, air beroksigen. 
Air adalah senyawa yang penting bagi semua bentuk kehidupan yang diketahui sampai saat ini dan menutupi hampir $71 \%$ permukaan bumi, begitu pula lebih dari $70 \%$ tubuh manusia tersusun atas air. Oksigen adalah molekul yang penting bagi kehidupan. Manusia tidak akan mampu bertahan hidup jika tidak ada ketersediaan oksigen bagi tubuhnya. Air dan oksigen merupakan dua unsur penting dalam kehidupan di antara sekian banyak unsur lainnya.Keberadaan keduanya merupakan syarat mutlak adanya suatu kehidupan di samping makanan., ${ }^{1,2}$

Pada manusia normal, oksigen dapat dipenuhi dengan bernafas. Kandungan oksigen diudara adalah sekitar 21\%. ${ }^{3}$ Oksigen dari udara akan digunakan paruparu dan disebarkan ke seluruh sel tubuh melalui pengangkutan oleh sel darah merah dengan membentuk oksihemoglobin. Hemoglobin yang 100\% jenuh dengan oksigen mampu mengikat 1,34 ml oksigen per gram hemoglobin. ${ }^{4}$

Salah satu parameter yang bisa dilihat adalah dari keadaan oksigen dalam darahnya. Seringkali keadaan oksigen tersebut kurang diperhatikan, padahal oksigen sangat mempengaruhi keadaan fisiologis lainnya.Kadar oksigen di dalam darah yang berikatan dengan hemoglobin disebut saturasi oksigen $\left(\mathrm{SpO}_{2}\right)^{5}$

Dewasa ini banyak sekali program latihan fisik yang ditawarkan, diantaranya adalah zumba. Pada saat berolahraga aliran darah dan penggunaan oksigen akan meningkat untuk mengangkut oksigen yang diperlukan pada otot selama latihan, sehingga dapat di duga bahwa tekanan oksigen darah arteri menurun sangat tajam, dan tekanan karbon dioksida dalam darah vena meningkat jauh diatas diatas normal. ${ }^{6,7}$

\section{METODE PENELITIAN}

Penelitian ini merupakan penelitian analitik eksperimental dengan menggunakan rancangan rancangan pre and post test. Dilakukan pada bulan November-Desember 2014 di beberapa center zumba di kota Manado yang berjumlah 31 orang yang memenuhi kriteria inklusi.

Pada penelitian ini variabel bebas adalah air mineral dan air beroksigen sedangkan variable terikat adalah saturasi oksigen. Prosedur penelitian dilakukan pemilihan anggota Zumba yang akan dijadikan sampel kemudian diberikan penjelasan mengenai prosedur penelitian. Responden yang bersedia mengikuti penelitian menandatangani formulir peresetujuan informed consent. Setiap responden mendapatkan dua perlakuan. Pada hari pertama responden melakukan senam zumba selama 1 jam sambil minum air mineral $930 \mathrm{ml}$, dan pada hari kedua responden kembali melakukan senam zumba selama 1 jam sambil minum air beroksigen $940 \mathrm{ml}$. Sebelum dan sesudah senam zumba nilai saturasi oksigen diukur.

Alat dan bahan yang digunakan antara lain pulse oksimetri, air mineral, air beroksigen, mikrotoys, timbangan berat badan, dan alat tulis menulis. Data yang didapat dianalisa dengan menggunakan uji Wilcoxon.

\section{HASIL PENELITIAN}

Tabel 1. Distribusi Frekuensi Berdasarkan Umur Responden

\begin{tabular}{ccc}
\hline $\begin{array}{c}\text { Umur Responden } \\
\text { (tahun) }\end{array}$ & $\mathrm{n}$ & $\%$ \\
\hline $16-25$ & 6 & 19,4 \\
$26-35$ & 23 & 74,2 \\
$>35$ & 2 & 6,5 \\
\hline Total & 31 & 100 \\
\hline
\end{tabular}

Tabel 2. Distribusi Frekuensi Berdasarkan Status Gizi IMT Responden

\begin{tabular}{ccc}
\hline Status Gizi IMT & $\mathrm{n}$ & $\%$ \\
\hline Normal & 29 & 93,5 \\
Obesitas & 2 & 6,5 \\
\hline Total & 31 & 100 \\
\hline
\end{tabular}

Tabel 3. Nilai Mean, SD, Minimum dan Maksimum Air Mineral

\begin{tabular}{cc}
\hline \multirow{2}{*}{ Nilai } & $\begin{array}{c}\text { Pemberian Air } \\
\text { Mineral }\end{array}$ \\
\hline
\end{tabular}




\begin{tabular}{lcc}
\hline & Sebelum & Sesudah \\
\hline Mean & 97,5 & 97,7 \\
Standar Deviasi & 0,9 & 1,03 \\
Minimum & 96 & 95 \\
Maksimum & 99 & 99 \\
\hline
\end{tabular}

Tabel 4. Nilai Mean, SD, Minimum dan Maksimum Air Beroksigen

\begin{tabular}{lcc}
\hline \multirow{2}{*}{\multicolumn{1}{c}{ Nilai }} & \multicolumn{2}{c}{$\begin{array}{c}\text { Pemberian } \mathrm{Air}_{\mathrm{O}} \\
\text { Tinggi }\end{array}$} \\
\cline { 2 - 3 } & Sebelum & Sesudah \\
\hline Mean & 97,6 & 98,7 \\
Standar Deviasi & 0,75 & 0,44 \\
Minimum & 96 & 98 \\
Maksimum & 99 & 99 \\
\hline
\end{tabular}

Tabel 5. Hasil Uji Statistik Menggunakan uji Wilcoxon

\begin{tabular}{ccc}
\hline & $\begin{array}{c}\text { Sebelum dan } \\
\text { Sesudah } \\
\text { Pemberian Air } \\
\text { Mineral }\end{array}$ & $\begin{array}{l}\text { Sebelum dan } \\
\text { Sesudah } \\
\text { Pemberian Air } \\
\mathrm{O}_{2} \text { Tinggi }\end{array}$ \\
\hline Nilai Z & 1,287 & 4,786 \\
Sig. & $\mathrm{p}=0,198$ & $\mathrm{p}=0,000$ \\
\hline
\end{tabular}

\section{BAHASAN}

Berdasarkan hasil penelitian uji statistic didapatkan 31 responden penelitian, sebagian besar mempunyai kategori umur 26-35 tahun yang berjumlah 23 responden $(74,2 \%)$, umur $16-25$ tahun berjumlah 6 responden (19,4\%),umur $>35$ tahun berjumlah 2 responden (6,5\%). Untuk IMT, dari 31 responden terdapat 29 responden dengan status gizi normal $(93,5 \%)$ dan 2 responden dengan status gizi obesitas (6,5\%).

Pada pengukuran saturasi oksigen sebelum pemberian air mineral menunjukan nilai terendah $96 \%$ dan tertinggi $99 \%$ dengan nilai rata-rata 97,5 $\pm 0,9$ sedangkan sesudah pemberian air mineral menunjukan nilai terendah 95\% dan tertinggi 99\% dengan nilai rata-rata $97,7 \pm 1,03$. Hasil tersebut menunjukkan terdapat perbedaan nilai saturasi oksigen sebelum dan sesudah pemberian air mineral dimana perubahan yang terjadi ialah peningkatan saturasi oksigen sesudah pemberian air mineral.
Pengukuran saturasi oksigen sebelum pemberian air beroksigen menunjukkan nilai terendah $96 \%$ dan tertinggi $99 \%$ dengan rata-rata $97,6 \pm 0,75$ sedangkan sesudah pemberian air beroksigen menunjukan nilai terendah $98 \%$ dan tertinggi 99\% dengan rata-rata 98,7 $\pm 0,44$. Hasil tersebut menunjukkan terdapat perbedaan nilai saturasi oksigen sebelum dan sesudah pemberian air beroksigen dimana perubahan yang terjadi ialah peningkatan saturasi oksigen sesudah pemberian air beroksigen.

Berdasarkan hasil analisis dengan menggunakan uji Wilcoxon pada penelitian ini didapatkan perbedaan bermakna pada pengukuran saturasi oksigen sebelum dan sesudah pemberian air beroksigen dengan nilai $\mathrm{p}=0,000<\alpha=0,05$ sedangkan terdapat perbedaan tidak bermakna pada pengukuran saturasi oksigen sebelum dan sesudah peberian air mineral dengan nilai $\mathrm{p}$ $=0,198>\alpha=0,05$. Hal ini sesuai dengan penelitian yang dilakukan oleh Ellyana (2011) bahwa terjadi peningkatan secara bermakna pada saturasi $\mathrm{O}_{2}$ namun terjadi peningkatan secara tidak bermakna pada $\mathrm{pH}$ urin setelah mengkonsumsi air beroksigen tinggi setelah berolahraga.

Seperti halnya zat-zat makanan, oksigen pun dapat masuk dan diserap oleh tubuh melalui saluran pencernaan. ${ }^{9}$ Penyerapan oksigen secara cepat terjadi di dalam usus. Penelitian Gurskaya dan Ivanon (1961) membuktikan bahwa terjadi penyerapan okigen didalam usus yang dapat meningkatkaan saturasi darah di dalam aorta dan vena porta hepatica. Absorbsi air oksigen pada saluran pencernaan dapat dinilai dengan pemeriksaan $\mathrm{pO}_{2}$ darah. Setelah 5 menit minum air beroksigen akan terjadi peningkatan $\mathrm{pO}_{2}$ darah. Selama $3-4$ jam kandungan oksigen tetap tinggi dalam darah. Absorbsi minuman beroksigen masuk ke kapiler membran mukosa saluran cerna kemudian ke vena portal dan masuk ke sirkulasi hati serta ke seluruh sirkulasi tubuh. Peningkatan oksigen dalam darah ini akan mencapai organ tubuh mengikuti jalur 
Pelealu, Moningka, Rumampuruk: Pengaruh air mineral...

hematogen oleh hemoglobin dari paru-paru ke jaringan. ${ }^{10,11}$ Menurut Jenskins et al (2002) penyerapan air beroksigen tinggi di dalam usus membutuhkan waktu 15 menit dan mengacu pada proses absorbsi makanan yang membutuhkan waktu 4 jam. $^{12}$

Penyerapan oksigen di dalam usus halus dimungkinkan karena bagian ini hanya dilapisi oleh sel-sel epitel silindris lapis tunggal. Oksigen akan masuk dengan cara difusi pasif melalui membran epitel yang membatasi lumen usus halus. ${ }^{2}$

Salah satu faktor utama terjadinya proses difusi dari usus menuju pembuluh darah ialah adanya perbedaan konsentrasi. Faktor lain yang memengaruhi penyerapan oksigen ialah membran sel usus yang terdiri dari lipid bilayer bersifat dapat ditembus oleh gas dan senyawa polar tidak bermuatan dengan berat molekul kecil. ${ }^{13}$

\section{SIMPULAN}

Terdapat peningkatan yang bermakna secara statistik dari rerata nilai saturasi oksigen pada pemberian air beroksigen tinggi dengan nilai $p=0,000<\alpha=0,05$ dibandingkan dengan pemberian air mineral dengan nilai $p=0,198>\alpha=0,05$.

\section{SARAN}

1. Diperlukan Penelitian lebih lanjut pada penelitian ini dengan menggunakan variabel yang lain seperti denyut nadi, frekuensi pernapasan, nilai faal paru, dan performa fisik dengan mengguna-kan lebih dari satu alat.

2. Diperlukan observasi lanjut setiap 15 menit pada nilai saturasi oksigen darah setelah pemberian air beroksigen tinggi untuk menilai berapa lama air beroksigen dapat menurunkan saturasi oksigen.

\section{DAFTAR PUSTAKA}

1. Lizuardi AB. Intervensi Air minum beroksigen berpotensi memperbaiki status lipida penderita gangguan fungsi paru [skripsi]. Bogor: Program
Sarjana,Institut Pertanian Bogor. 2013

2. Zakaria, F. R., Tan, M. I., dan Kadarsya. Penyerapan Oksigen melalui Sistem Pencernaan dan Keamanannya. Departemen Teknologi Pangan dan Gizi. FATETA. Institut Pertanian Bogor, Bogor.2005.

3. Oxtoby DW, Gillis HP, Nachtrieb NH, Campio A. Principles of Modern Chemistry. California Thomson books / Cole Publisher. 2007

4. Schwartz, NB. Carbohydrate Metabolism II: Special Pathway. In: Devlin TM. Ed. textbook of Biochemistry with Clinical Correlations (3rd ed). WileyLiss. 1992

5. Schutz S. Oxygen saturation monitoring by pulse oximetry. AACN Procedure manual for critical care. $4^{\text {th }}$ ed.

6. Porcari J. Zumba: is the "fitness party" a good workout. Jsmm. 2012;11:357-8.

7. Guyton AC, Hall JE. Fisiologi olahraga. In: Rachman LY, Hartanto H, Novrianti A, Wulandari $\mathrm{N}$ editors. Buku ajar fisiologi kedokteran. $11^{\text {th }}$ ed. Jakarta; EGC. 2007;1111-23

8. Ellyana NS, Sarosa H, Hussaana A. perbedaan pengaruh air beroksigen tinggi dengan air mineral terhadap saturasi oksigen dan pH urin. 2011. Vol 3(2);162-7

9. Rhoades RA, Bell DR. Medical phisiology. Lippincott Williams \& Wilkins, Maryland. 2009

10.Gurskaya NV, Ivanov KP. Gaseous equilibrium between blood and the lumen of the intestine. Bulletin of experimental biology and medicine 1961; vol. 50(3):910-2.

11.Pakdaman A. Oxygen enriched watern and oral oxygen therapy. German copyright law 1985; 1-20

12.Jenskins A, Moreland M, Waddell TB, Fernhall B. Effects of oxygenated water in percent oxygen saturatin and performing during exercise. Med Sci Sport Exerc 2002; 33:1-14

13.Ramadhani I. efek konsumsi air minum penambah oksigen tehadap proloferasi sel limfosit manusia [skripsi]. Bogor: Institut Pertanian Bogor, 2009. 